\title{
ANALISIS FAKTOR-FAKTOR RESIKO PENYEBAB MUSCULOSKELETAL DISORDERS DAN STRES KERJA (STUDI KASUS DI PLN PLTGU CILEGON)
}

\author{
Ahmad Fauzi Dwi Hartono ${ }^{1)}$ dan Hartomo Soewardi ${ }^{2)}$ \\ ${ }^{1)}$ PT PLN (Persero) Transmisi Jawa Bagian Tengah \\ ${ }^{2)}$ Magister Teknik Industri, Fakultas Teknologi Industri, Universitas Islam Indonesia, Yogyakarta \\ e-mail: ${ }^{1)}$ hartonofauzi.ahmad@gmail.com ; ${ }^{2}$ hartomo@uii.ac.id
}

\begin{abstract}
ABSTRAK
Pengoperasian pembangkit energi listrik memiliki tingkat kompleksitas tinggi dan risiko bahaya keselamatan dan kesehatan pada pekerja. Oleh karena itu dibutuhkan kondisi stamina tubuh sehat jasmani dan rohani. Berdasarkan survei awal yang dilakukan pada bagian operasi dan pemeliharaan PLN PLTGU, diperoleh tingkat risiko musculoskeletal disorders: 97\% sedang dan 3\% tinggi, tingkat risiko stres kerja: 80\% sedang dan 3\% tinggi, tingkat risiko kelelahan kerja: 83\% tinggi dan 17\% sedang. Tujuan penelitian ini adalah untuk mengidentifikasi faktor-faktor risiko penyebab musculoskeletal disorders dan stres kerja serta memberikan rekomendasi perbaikan yang diperlukan. Metode yang digunakan adalah ergonomics evaluation checklist dan analisis statistik non parametric dengan metode Cochran's Q Tes. Hasil penelitian ini mengidentifikasi bahwa risiko musculoskeletal disorders disebabkan oleh aktivitas berulang, membungkuk, menunduk, mendongak, menjangkau berlebihan, berdiri, dan jari menekan. Sedangkan penyebab risiko stres kerja yaitu faktor fisik lingkungan kerja: kebisingan, pencahayaan, suhu ruang dan faktor somatis: kondisi tubuh yang mudah lelah dan sakit, sehingga perlu dilakukan perbaikan untuk faktor tersebut selain perlu adanya pengembangan pengetahuan tentang kesehatan kerja dan ergonomi, standarisasi alat pelindung diri, aktivitas olahraga yang teratur dan peningkatan hidup sehat tanpa rokok.
\end{abstract}

Kata Kunci: musculoskeletal disorders, stres kerja, aktivitas berulang, sikap kerja tidak alamiah, faktor fisik lingkungan kerja, faktor somatis.

\begin{abstract}
The operation of an electric power plant has a high degree of complexity and a danger of safety and health risks to workers. Therefore, it is necessary to have physical and spiritual health. Based on a preliminary survey conducted in the operation and maintenance section of the PLTGU, the level of risk of musculoskeletal disorders was obtained: 97\% moderate and 3\% high, the level of risk of work stress: 80\% moderate and 3\% high, the level of work fatigue risk: $83 \%$ high and $17 \%$ medium. The purpose of this study is to identify risk factors for causes of musculoskeletal disorders and work stress and provide recommendations for improvements that are needed. The method used is ergonomics evaluation checklist and non parametric statistical analysis using the Cochran's $Q$ Test method. The results of this study identified that the risk of musculoskeletal disorders is caused by repetitive activity, bending, looking down, looking up, reaching excessively, standing up, and pressing fingers. While the causes of the risk of work stress are physical factors of the work environment: noise, lighting, room temperature and somatic factors: body conditions that are easily tired and sick, so that improvements need to be made to these factors besides the development of knowledge about occupational health and ergonomics, standardization of protective equipment self, regular exercise activities and increased healthy living without smoking.
\end{abstract}

Keywords: musculoskeletal disorders, work stress, repetitive activity, unnatural working attitudes, physical factors in the work environment, somatic factors.

\section{PENDAHULUAN}

PT PLN PLTGU Cilegon merupakan unit pembangkit tenaga listrik yang terdiri atas 2 gas turbine berkapasitas 2 X $240 \mathrm{MW}$ dan 1 steam turbine berkapasitas 260 MW. Energi listrik yang dihasilkan disalurkan melalui jaringan transmisi 150 kV ke Gardu Induk Cilegon yang sudah terhubung dengan jaringan interkoneksi Transmisi Jawa - Madura - Bali. Pengoperasian pembangkit energi listrik memiliki tingkat kompleksitas tinggi dan risiko bahaya keselamatan dan kesehatan pada pekerja. Oleh karena itu dibutuhkan kondisi stamina tubuh sehat jasmani dan rohani.

Hasil survei awal total skor individu 30 orang pekerja diketahui: 1) tingkat risiko sistem musculosketal: 3\% tinggi dan 97\% sedang; 2) tingkat risiko stres kerja: 3\% tinggi, $80 \%$ 
sedang dan 17\% rendah; 3) tingkat kelelahan: $83 \%$ tinggi dan $17 \%$ sedang; 4) jumlah penderita gejala musculoskeletal disorders: carpal turner syndrome: 1 pekerja dan fatigue: 2 pekerja.

Tujuan dilakukannya penelitian ini adalah mengidentifikasi dan menganalisis faktor-faktor risiko penyebab terjadinya musculoskeletal disorders dan stres kerja serta memberikan rekomendasi perbaikan yang diperlukan. Manfaat yang diperoleh dari penelitian ini adalah memberikan bahan informasi tentang faktor-faktor penyebab muskuluskeletal disorders dan stres kerja dan upaya-upaya untuk mengendalikan potensi bahaya risiko tersebut kepada manajemen PLN PLTGU Cilegon

Berdasarkan hasil survei awal dan uraian latar belakang tersebut diatas, maka penelitian ini berusaha analisis faktor-faktor resiko penyebab musculoskeletal disorders dan stres kerja di PLN PLTGU Cilegon.

\section{STUDI PUSTAKA \\ Musculoskeletal Disorders (MSDs)}

Ada beberapa defisini yang berkaitan dengan keluhan musculoskeletal. Menurut Occupational Health and Safety Council of Ontario (OHSCO) tahun 2007, keluhan muskuloskeletal adalah serangkaian sakit pada tendon, otot, dan saraf. Aktifitas dengan tingkat pengulangan tinggi dapat menyebabkan kerusakan pada jaringan sehingga dapat menimbulkan rasa nyeri dan rasa tidak nyaman pada otot. Keluhan muskuloskeletal dapat terjadi walaupun gaya yang dikeluarkan ringan dan postur kerja yang memuaskan.

Keluhan otot skeletal pada umumnya terjadi karena kontraksi otot yang berlebihan akibat pemberian beban kerja yang terlalu berat dengan durasi pembebanan panjang. Sebaliknya, keluhan otot kemungkinan tidak terjadi apabila kontraksi otot hanya berkisar antar 15\% - 20\% dari kekuatan otot maksimum. Namun apabila kontraksi otot melebihi 20\%, maka peredaran darah ke otot berkurang menurut tingkat kontraksi yang dipengaruhi oleh besarnya tenaga yang diperlukan. Suplai oksigen ke otot menurun, proses metabolisme karbohidrat terhambat dan sebagai akibatnya terjadi penimbunan asam laktat yang menyebabkan timbulnya rasa nyeri otot [1] [2].

Secara garis besar keluhan otot dapat dikelompokkan menjadi dua, yaitu: 1) keluhan sementara (reversible), yaitu keluhan otot yang terjadi pada saat otot menerima beban statis, namun demikian keluhan tersebut akan segera hilang apabila pembebanan dihentikan, 2) keluhan menetap (persistent), yaitu keluhan otot yang bersifat menetap. Walaupun pembebanan kerja telah dihentikan, namun rasa sakit pada toto masih terus berlanjut.

Peter Vi menjelaskan bahwa ada beberapa faktor yang menyebabkan terjadinya keluhan otot skeletal: 1) peregangan otot yang belebihan (faktor beban berat) yaitu peregangan otot yang berlebihan (over exertion) dimana aktivitas pekerjaan yang menuntut pengerahan tenaga yang besar, seperti mengangkat, mendorong, menarik dan menahan beban yang berat; 2) aktivitas berulang (faktor frekuensi) yaitu aktivitas yang yang dilakukan secara berulang dengan sedikit variasi, dapat menimbulkan kelelahan dan ketegangan otot dan tendon karena kurang istirahat (relaksasi); 3) sikap kerja tidak alamiah (faktor postur janggal) yaitu sikap kerja yang menyebabkan posisi bagian tubuh bergerak menjauhi posisi alamiah, misalnya tangan terangkat, punggung membungkuk, kepala terangkat keatas [3]. Semakin jauh posisi bagian tubuh dari pusat gravitasi tubuh, maka semakin tinggi pula resiko terjadinya keluhan otot skeletal. Sikap kerja tidak alamiah ini pada umumnya karena karakteristik tuntutan tugas, alat kerja dan stasiun kerja tidak sesuai dengan kemampuan dan keterbatasan pekerja [2][4][5][6]). 4 faktor penyebab sekunder: 1) tekanan, terjadinya tekanan pada jaringan otot yang lunak. Contoh pada saat tangan harus memegang alat, maka jaringan otot yang lunak akan menerima tekanan langsung dari pegangan alat, dan apabila hal ini sering terjadi, dapat menyebabkan rasa nyeri toto yang menetap; 2) getaran, getaran dengan frekuensi tinggi akan menyebabkan kontraksi otot bertambah. Kontraksi statis ini menyebabkan peredaran darah tidak lancar, penimbunan asam laktat meningkat dan akhirnya timbul rasa nyeri otot [1]; 3) mikroklimat, paparan suhu dingin yang 
berlebihan dapat menurunkan kelincahan, kepekaan dan kekuatan pekerja sehingga gerakan pekerja menjadi lamban, sulit bergerak yang disertai dengan menurunnya kekuatan otot [7][8][9].

Penyebab lain yang berperan musculoskeletal disorders antara lain: 1) umur: keluhan muskuloskeletal mulai dirasakan pada usia kerja, yaitu pada usia 25 - 65 tahun biasanya akan mulai dirasakan pada usia 35 tahun dan akan semakin meningkat semakin bertambahnya usia. Hal ini terjadi karena pada usia setengah baya, kekuatan dan ketahanan otot akan meningkat [10]; 2) jenis kelamin: jenis kelamin sangat mempengaruhi tingkat risiko keluhan otot. Hal ini terjadi karena secara fisiologis, kemampuan otot wanita lebih rendah daripada pria; 3) kebiasaan merokok: semakin lama dan semakin tinggi tingkat frekuensi merokok, semakin tinggi pula keluhan otot yang dirasakan. Kebiasaan merokok dapat menurunkan kapasitas paru-paru sehingga kemampuan untuk mengkonsumsi oksigen menurun; 4) kesegaran jasmani: tingkat kesegaran tubuh yang rendah akan mempertinggi risiko terjadinya keluhan otot; 5) kekuatan fisik: secara fisiologis ada yang dilahirkan dengan struktur otot yang mempunyai kekuatan fisik lebih kuat dibandingkan dengan yang lainnya; 6) ukuran tubuh (antropometri): keluhan muskuloskeletal yang terkait dengan ukuran tubuh lebih disebabkan oleh kondisi keseimbangan struktur rangka di dalam menerima beban, baik beban berat tubuh maupun beban tambahan.

\section{Stres Kerja}

Faktor penyebab terjadinya stres tergantung dengan sifat dan kepribadian seseorang. Suatu keadaan yang dapat menimbulkan stres pada seseorang tetapi belum tentu akan menimbulkan hal yang sama terhadap orang lain. Perbedaan reaksi antara individu tersebut sering disebabkan faktor psikologis dan sosial yang dapat merubah dampak stressor bagi individu [11]

Manuaba memberikan definisi sebagai berikut: stres adalah segala rangsangan atau aksi dari tubuh manusia baik yang berasal dari luar maupun dari dalam tubuh itu sendiri yang dapat menimbulkan bermacam-macam dampak yang merugikan mulai menurunnya kesehatan sampai kepada dideritanya penyakit. Dalam kaitannya dengan pekerjaan, semua dampak dari stres tersebut akan menjurus kepada menurunnya performansi, efisiensi dan produktivitas kerja yang bersangkutan [6].

Kaitannya dengan tugas-tugas dan pekerjaan di tempat kerja, Clark dan Wantoro mengelompokkan penyebab stres (stressor) ditempat kerja menjadi tiga kategori yaitu stressor fisik, psikofisik dan psikologis [12][13]. Selanjutnya Cartwright mencoba memilah-milah penyebab stres akibat kerja menjadi 6 kelompok antara lain: 1) faktor fisik lingkungan kerja: meliputi keadaan fisik lingkungan kerja seperti kebisingan, suhu, pencahayaan yang tidak nyaman, stasiun kerja tidak ergonomis, kerja shift dan jam kerja yang panjang; 2) faktor peran individu dalam organisasi kerja: beban tugas yang bersifat mental dan tanggung jawab dari suatu pekerjaan lebih memberikan stres yang tinggi dibandingkan dengan beban kerja fisik; 3) faktor pengembangan karier: perasaan tidak nyaman dalam pekerjaan, posisi dan pengembangan karier mempunyai dampak cukup penting sebagai penyebab terjadinya stres [14]. Menurut Wantoro faktor pengembangan karier yang dapat menjadi pemicu stres adalah ketidakpastian pekerjaan dan promosi berlebihan atau kurang [13]; 4) faktor struktur organisasi dan suasana kerja: penyebab stres yang berhubungan dengan organisasi dan suasana kerja biasanya berawal dari budaya organisasi dan model manajemen. Hubungan kurang baik antar karyawan ditempat kerja adalah faktor yang potensial sebagai penyebab terjadinya stres. Kecurigaan antara pekerja, kurangnya komunikasi, ketidaknyamanan dalam melakukan pekerjaan merupakan tandatanda adanya stres akibat kerja [15]; 5) faktor somatis (fisik): kesehatan, gizi, pola makan, jenis kelamin, usia; 6) faktor ergonomik: postur tubuh yang tidak seimbang dan berlangsung dalam jangka waktu yang lama akan mengakibatkan stres pada bagian tubuh tertentu, yang disebut dengan postural stress. 


\section{METODOLOGI PENELITIAN}

Subjek pada penelitian ini adalah pekerja yang berjumlah 30 orang yang berumur 25 sampai 40 tahun dan berjenis kelamin laki-laki dan perempuan, berbadan sehat pada bidang operasi dan pemeliharaan.

Ruang lingkup penelitian ini adalah menganalisis faktor-faktor resiko penyebab musculoskeletal disorders dan stres kerja dalam mengoperasikan dan memelihara PLTGU Cilegon yang berlokasi di jalan Raya Bojonegara - Salira Desa Margasari Kec. Pulo Ampel Kab. Serang Provinsi Banten.

Variabel penelitian risiko penyebab musculoskeletal disorders adalah 1) peregangan otot yang belebihan; 2) aktivitas berulang; 3) sikap kerja tidak alamiah; 4) faktor sekunder (tekanan - getaran - mikroklimat). Sedangkan variable penelitan risiko penyebab stres kerja adalah 1) faktor fisik lingkungan kerja; 2) faktor peran individu dalam organisasi kerja; 3) faktor pengembangan karier; 4) faktor struktur organisasi dan suasana kerja; 5) faktor somatis; 6) faktor ergonomik.

Instrumen penelitian yang digunakan untuk mendapatkan data dan mengolah data yang digunakan antara lain: 1) kuesioner Nordic body map (NBM); 2) kuesioner stres kerja; 3) kuesioner kelelahan subjektif; 4) ergonomics evaluation checklist; 5) aplikasi SPSS 22. Penelitian ini menggunakan beberapa tahapan metode yang dapat dilihat pada Gambar 1 .

\section{HASIL DAN PEMBAHASAN \\ Hasil Uji Statistik Nonparametrik}

Setelah dilakukan uji statistik nonparametric metode Cochran Q Test didapat hasil seperti ditunjukan Tabel 1.

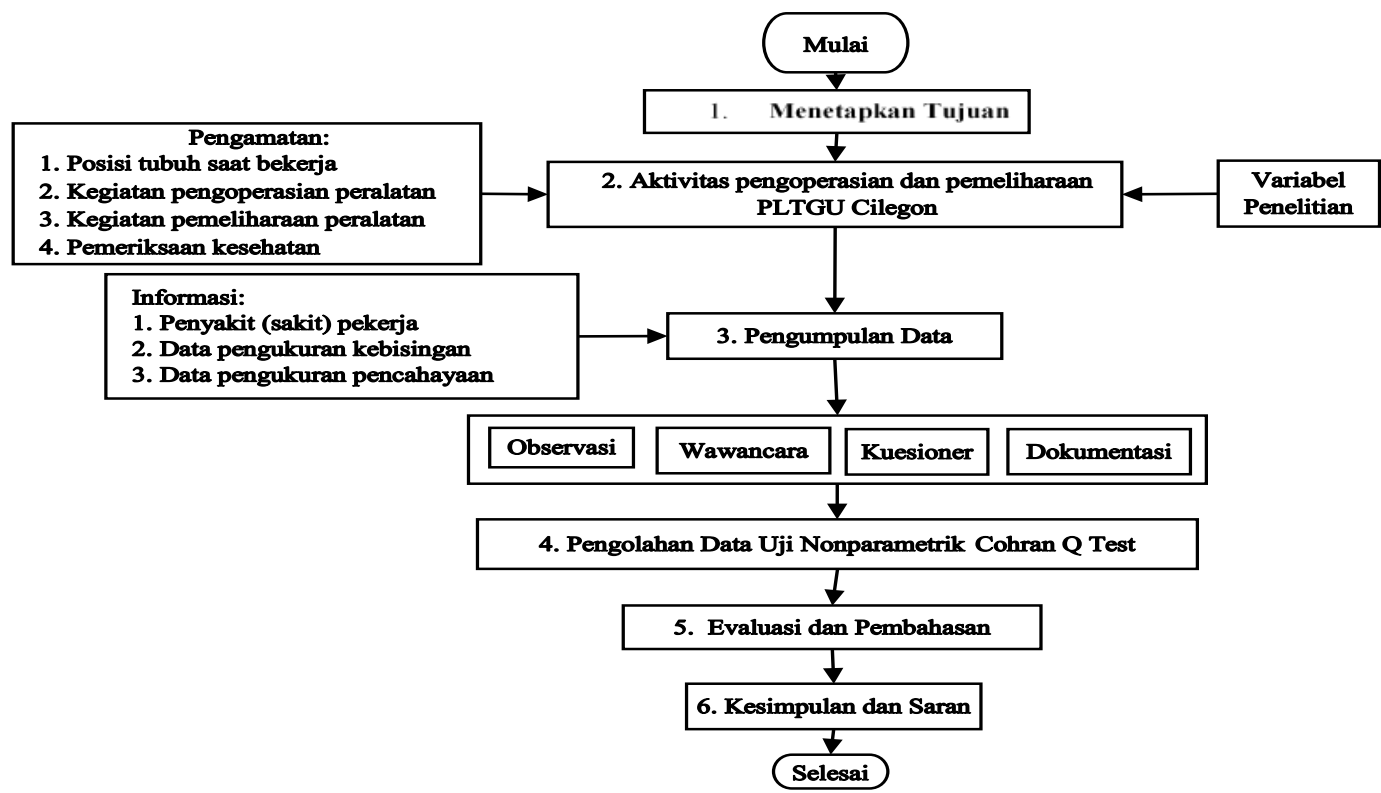

Gambar 1. Tahapan Penelitian

Tabel 1. Hasil Uji Cochran Q Test Faktor-Faktor Risiko Penyebab Musculoskeletal Disorders

\begin{tabular}{|c|c|c|c|c|c|c|c|c|c|c|}
\hline No & Variabel & $\begin{array}{c}\text { Statistic } \\
\text { Hitung }\end{array}$ & $\begin{array}{l}\text { Sig. } \\
(\alpha) \\
5 \%\end{array}$ & $\begin{array}{l}\text { Derajat } \\
\text { Kebeba } \\
\text { san (df) }\end{array}$ & $\begin{array}{l}\text { Statistic } \\
\text { Table }\end{array}$ & $\begin{array}{c}\text { Statistic } \\
\text { Hitung < } \\
\text { Statistic } \\
\text { Table }\end{array}$ & $\begin{array}{l}\text { Asym } \\
\text { p. Sig. }\end{array}$ & $\begin{array}{l}\text { Prob. } \\
5 \%\end{array}$ & $\begin{array}{c}\text { Asymp.Sig > } \\
\text { Probabilitas }\end{array}$ & Keputusan \\
\hline 1 & $\begin{array}{l}\text { Peregangan } \\
\text { Otot } \\
\text { Berlebihan }\end{array}$ & 18.5 & $5 \%$ & 2 & 5.99 & $18,5>5,99$ & 0,00 & 0,05 & $0,00<0,05$ & $\begin{array}{c}\text { H0 } \\
\text { Ditolak }\end{array}$ \\
\hline 2 & $\begin{array}{l}\text { Aktivitas } \\
\text { Berulang }\end{array}$ & 3,571 & $5 \%$ & 1 & 3,84 & $3,571<3,84$ & 0,125 & 0,05 & $0,125>0,05$ & $\begin{array}{c}\text { Ho } \\
\text { Diterima }\end{array}$ \\
\hline 3 & $\begin{array}{l}\text { Sikap Kerja } \\
\text { Tidak } \\
\text { Alamiah }\end{array}$ & 9,091 & $5 \%$ & 5 & 11.07 & $9,091<11,07$ & 0,105 & 0,05 & $0,105>0,05$ & $\begin{array}{c}\text { Ho } \\
\text { Diterima }\end{array}$ \\
\hline 4 & $\begin{array}{l}\text { Faktor } \\
\text { Sekunder }\end{array}$ & 10,714 & $5 \%$ & 3 & 9,49 & $10,714>9,49$ & 0,013 & 0,05 & $0,013<0,05$ & $\begin{array}{c}\text { H0 } \\
\text { Ditolak }\end{array}$ \\
\hline
\end{tabular}


Tabel 2. Hasil Uji Cochran Q Test Faktor-Faktor Risiko Penyebab Stres Kerja

\begin{tabular}{|c|c|c|c|c|c|c|c|c|c|c|}
\hline No & Variabel & $\begin{array}{l}\text { Stat. } \\
\text { Hitung }\end{array}$ & $\begin{array}{l}\text { Sig. } \\
(\alpha): \\
5 \%\end{array}$ & $\begin{array}{l}\text { Derajat } \\
\text { Kebeba } \\
\text { san (df) }\end{array}$ & $\begin{array}{l}\text { Stat. } \\
\text { Table }\end{array}$ & $\begin{array}{c}\text { Stat. Hitung < } \\
\text { Stat. Table }\end{array}$ & $\begin{array}{l}\text { Asym } \\
\text { p. Sig. }\end{array}$ & $\begin{array}{c}\text { Prob. } \\
5 \%\end{array}$ & $\begin{array}{c}\text { Asymp.Sig > } \\
\text { Prob. }\end{array}$ & Keputusan \\
\hline 1 & $\begin{array}{l}\text { Faktor } \\
\text { Fisik } \\
\text { Lingkungan } \\
\text { Kerja }\end{array}$ & 6,368 & $5 \%$ & 5 & 11,07 & $6,368<11,07$ & 0,272 & 0,05 & $0,272>0,05$ & $\begin{array}{c}\text { H0: } \\
\text { Diterima }\end{array}$ \\
\hline 2 & $\begin{array}{l}\text { Faktor Peran } \\
\text { Individu } \\
\text { Dalam } \\
\text { Organisasi } \\
\text { Kerja }\end{array}$ & 11,556 & $5 \%$ & 2 & 5,99 & $11.556>5.99$ & 0.003 & 0.05 & $0,003<0,05$ & $\begin{array}{c}\text { Ho: } \\
\text { Ditolak }\end{array}$ \\
\hline 3 & $\begin{array}{l}\text { Faktor } \\
\text { Pengembang } \\
\text { an Karier } \\
\text { Faktor }\end{array}$ & 8,067 & $5 \%$ & 1 & 3,84 & $8,067>3,84$ & 0,007 & 0,05 & $0,007<0,05$ & $\begin{array}{l}\text { Ho: } \\
\text { Ditolak }\end{array}$ \\
\hline 4 & $\begin{array}{l}\text { Struktur } \\
\text { Organisasi } \\
\text { dan Suasana } \\
\text { Kerja }\end{array}$ & 31,438 & $5 \%$ & 6 & 12,59 & $31,438>12,59$ & 0,000 & 0,05 & $0<0,05$ & $\begin{array}{c}\text { Ho: } \\
\text { Ditolak }\end{array}$ \\
\hline 5 & $\begin{array}{l}\text { Faktor } \\
\text { Somatis }\end{array}$ & 4,222 & $5 \%$ & 2 & 5,99 & $4,222<5,99$ & 0,121 & 0,05 & $0,121>0,05$ & $\begin{array}{c}\text { Ho: } \\
\text { Diterima }\end{array}$ \\
\hline 6 & $\begin{array}{l}\text { Faktor } \\
\text { Ergonomi }\end{array}$ & 52,002 & $5 \%$ & 9 & 16,92 & $52>16.92$ & 0.00 & 0,05 & $0<0,05$ & $\begin{array}{c}\text { Ho: } \\
\text { Ditolak }\end{array}$ \\
\hline
\end{tabular}

Tabel 3. Keluhan Nordic Body Map

\begin{tabular}{clcc}
\hline \multirow{2}{*}{ No } & \multicolumn{1}{|}{ Jenis Keluhan } & \multicolumn{2}{c}{ Sakit } \\
\cline { 3 - 4 } & & Jumlah & Persen (\%) \\
\hline 1 & Sakit/kaku di leher bagian atas & 2 & 6,7 \\
2 & Sakit di punggung & 2 & 6,7 \\
3 & Sakit/kaku di leher bagian bawah & 1 & 3,3 \\
\hline
\end{tabular}

Tabel 4. Hasil Klasifikasi Subjektivitas Tingkat Risiko Sistem Muskuloskeletal Berdasarkan Total Skor Individu

\begin{tabular}{cccccl}
\hline No & $\begin{array}{c}\text { Total Skor Keluhan } \\
\text { Muskuluskeletal }\end{array}$ & $\begin{array}{c}\text { Tingkat } \\
\text { Risiko }\end{array}$ & $\begin{array}{c}\text { Kategori } \\
\text { Risiko }\end{array}$ & $\begin{array}{c}\text { Hasil } \\
(\%)\end{array}$ & $\begin{array}{c}\text { Tindakan } \\
\text { Perbaikan }\end{array}$ \\
\hline 2 & $\mathbf{2 1 - 4 1}$ & $\mathbf{2}$ & Sedang & $\mathbf{9 7 \%}$ & $\begin{array}{l}\text { Mungkin diperlukan adanya tindakan } \\
\text { dikemudian hari }\end{array}$ \\
3 & $\mathbf{4 2 - 6 2}$ & $\mathbf{3}$ & Tinggi & $\mathbf{3 \%}$ & Diperlukan tindakan segera \\
\hline
\end{tabular}

Tabel 5. Hasi Klasifikasi Tingkat Risiko Stres Akibat Kerja Berdasarkan Total Skor Individu

\begin{tabular}{cccccl}
\hline No & $\begin{array}{c}\text { Total Skor } \\
\text { Stres Individu }\end{array}$ & $\begin{array}{c}\text { Tingkat } \\
\text { Risiko Stres }\end{array}$ & $\begin{array}{c}\text { Kategori } \\
\text { Stres }\end{array}$ & $\begin{array}{c}\text { Hasil } \\
(\%)\end{array}$ & $\begin{array}{c}\text { Tindakan } \\
\text { Perbaikan }\end{array}$ \\
\hline 2 & $\mathbf{1 0 5 - \mathbf { 1 3 9 }}$ & $\mathbf{2}$ & Sedang & $\mathbf{8 0 \%}$ & $\begin{array}{l}\text { Diperlukan kontrol terhadap gejala stres } \\
\text { dikemudian hari }\end{array}$ \\
3 & $\mathbf{7 0 - 1 0 4}$ & $\mathbf{3}$ & Tinggi & $\mathbf{3 \%}$ & $\begin{array}{l}\text { Diperlukan kontrol terhadap stres di } \\
\text { tempat kerja segera }\end{array}$ \\
\hline
\end{tabular}

Tabel 6. Hasil Klasifikasi Tingkat dan Kategori Kelelahan Subjektif Berdasarkan Total Skor Individu

\begin{tabular}{cccccl}
\hline No & $\begin{array}{c}\text { Total Skor } \\
\text { Individu }\end{array}$ & $\begin{array}{c}\text { Tingkat } \\
\text { Kelelahan }\end{array}$ & $\begin{array}{c}\text { Kategori } \\
\text { Kelelahan }\end{array}$ & $\begin{array}{c}\text { Hasil } \\
(\%)\end{array}$ & $\begin{array}{c}\text { Tindakan } \\
\text { Perbaikan }\end{array}$ \\
\hline 2 & $\mathbf{2 2 - 4 4}$ & $\mathbf{2}$ & Sedang & $\mathbf{1 7 \%}$ & Mungkin diperlukan tindakan dikemudian hari \\
3 & $\mathbf{4 5 - 6 7}$ & $\mathbf{3}$ & Tinggi & $\mathbf{8 3 \%}$ & Diperlukan tindakan segera \\
\hline
\end{tabular}




\section{Faktor-Faktor Risiko \\ Musculoskeletal Disorders \\ Peregangan Otot Berlebihan}

Hipotesis (H0) yang dipergunakan adalah pekerja membutuhkan kekuatan atau energi besar, pekerja mengangkat beban berat dan pekerja mendorong beban berat selama bekerja mempunyai efek pengaruh terhadap peregangan otot berlebihan.

Jawaban kuesioner: 1) energi besar: 67\%; 2) mengangkat beban 19\%; 3) mendorong beban $14 \%$. Chi-square distribution table untuk derat kebebasan $\mathrm{df}=2$ dan tingkat signifikansi $\alpha=5 \%$, didapatkan nilai 5,99. Hasil uji Cochran: 1) statistic table sebesar 18,5; dan 2) asymptotic significance sebesar 0. Pengambilan keputusan: 1) membandingkan antara nilai statistik hitung dengan nilai statistik table: 18,5 $>$ 5,99, maka Ho Ditolak; 2) membandingkan antara nilai asymptotic significance dengan nilai probabilitas: $0<$ 0,05, maka H0 Ditolak.

Kesimpulan: Pekerjaan mengangkat, mendorong dan menarik beban berat tidak membutuhkan energi besar maupun peregangan otot yang berlebihan, maka peregangan otot berlebihan bukan penyebab risiko musculoskeletal disorder.

\section{Aktivitas Berulang}

Hipotesis (H0) yang dipergunakan adalah pekerjaan dilakukan secara berulang-ulang dan pekerjaan dilakukan dengan cepat selama bekerja mempunyai efek pengaruh terhadap risiko musculoskeletal disorder.

Jawaban kuesioner: 1) pekerjaan berulang $76 \%$; 2) pekerjaan cepat 52\%. Chi-square distribution table untuk derat kebebasan $\mathrm{df}=1$ dan tingkat signifikansi $\alpha=5 \%$, didapatkan nilai 3,84. Hasil uji Cochran:1) statistic hitung sebesar 3,571; dan 2) asymptotic significance sebesar 0,125. Pengambilan keputusan: 1) membandingkan antara nilai statistik hitung dengan nilai statistik table: 3,571 $<\mathbf{3 , 8 4}$, maka Ho Diterima; 2) membandingkan antara nilai asymptotic significance dengan nilai probabilitas: 0,125 > 0,05, maka H0 Diterima.

Kesimpulan: Pekerjaan dilakukan secara berulang-ulang dan dilakukan dengan cepat selama bekerja mempunyai efek pengaruh terhadap risiko musculoskeletal disorder.

\section{Sikap Kerja Tidak Alamiah}

Hipotesis (H0) yang dipergunakan adalah postur pekerja tidak alamiah seperti membungkuk, menjangkau, memutar badan, menekan, berdiri dan lain-lain selama bekerja mempunyai efek pengaruh terhadap risiko musculoskeletal disorder.

Jawaban kuesioner: 1) postur janggal 19\%; 2) menjangkau dan memutar badan 43\%; 3) menekan 43\%; 4) berdiri seharian 19\%; 5) membungkuk sampai di bawah lutut 19\%; 6) postur janggal selama menggunakan peralatan 19\%. Chi-square distribution table untuk derat kebebasan $\mathrm{df}=5$ dan tingkat signifikansi $\alpha=5 \%$, didapatkan nilai 11,07. Hasil uji Cochran: 1) statistic hitung sebesar 9,091; dan 2) asymptotic significance sebesar 0,105. Pengambilan keputusan: 1) membandingkan antara nilai statistik hitung dengan nilai statistik table: 9,091 < 11,07, maka Ho Diterima; 2) membandingkan antara nilai asymptotic significance dengan nilai probabilitas: 0,105 > 0,05, maka H0 Diterima.

Kesimpulan: postur pekerja tidak alamiah seperti membungkuk, menjangkau, memutar badan, menekan, berdiri dan lain-lain selama bekerja mempunyai efek pengaruh terhadap risiko musculoskeletal disorder.

\section{Faktor Sekunder}

Hipotesis (H0) yang dipergunakan adalah pekerjaan menekan, menggunakan peralatan yang bergetar, bekerja berdekatan dengan sumber panas, bekerja diruangan bersuhu dingin merupakan faktor sekunder penyebab terjadinya musculoskeletal disorders.

Jawaban kuesioner: 1) menekan 43\%; 2) peralatan bergetar $48 \%$; 3) dekat sumber panas $81 \%$; 4) ruangan dingin 38\%. Chi-square distribution table untuk derat kebebasan $\mathrm{df}=3$ dan tingkat signifikansi $\alpha=5 \%$, didapatkan nilai 9,49. Hasil uji Cochran: 1) statistic hitung sebesar 10,714; dan 2) asymptotic significance sebesar 0,013. Pengambilan keputusan: 1) membandingkan antara nilai statistik hitung dengan nilai statistik table: 10,714 > 9,49, maka Ho Ditolak; 2) membandingkan antara nilai asymptotic significance dengan nilai probabilitas: 0,013 < 0,05, maka H0 Ditolak. 
Kesimpulan: pekerjaan menekan, menggunakan peralatan yang bergetar, bekerja berdekatan dengan sumber panas dan bekerja diruangan bersuhu dingin bukan merupakan faktor sekunder penyebab terjadinya musculoskeletal disorders.

\section{Faktor-Faktor Risiko Penyebab Risiko Stres Kerja \\ Faktor Fisik Lingkungan Kerja}

Hipotesis (H0) yang dipergunakan adalah pencahayaan mencukupi dan tidak menyilaukan di stasiun kerja, kebisingan di atas 85 dBA dan tidak mengganggu komunikasi dan ruangan bersuhu dingin merupakan faktor fisik lingkungan kerja yang menyebabkan stres kerja.

Jawaban kuesioner: 1) pencahayaan cukup 19\%; 2) pencahayaan menyilaukan 33\%; 3) ruang kerja terlalu bising 38\%; 4) kebisingan di atas 85 dBA 48\%; 5) sering memasuki ruangan bising 48\%; 6) bekerja di ruangan bersuhu dingin 38\%. Chi-square distribution table untuk derat kebebasan $\mathrm{df}=5$ dan tingkat signifikansi $\alpha=5 \%$, didapatkan statistic table sebesar 11,07. Hasil uji Cochran: 1) statistic hitung sebesar 6,368; dan 2) asymptotic significance sebesar 0,272. Pengambilan keputusan: 1) membandingkan antara nilai statistik hitung dengan nilai statistik table: 6,368 < 11,07, maka H0 Diterima; 2) membandingkan antara nilai asymptotic significance dengan nilai probabilitas: 0,272 > 0,05, maka H0 Diterima.

Kesimpulan: pencahayaan mencukupi dan tidak menyilaukan di stasiun kerja, kebisingan di atas 85 dBA namun tidak mengganggu komunikasi serta ruangan kerja bersuhu dingin merupakan faktor fisik lingkungan kerja yang menyebabkan stres kerja.

\section{Faktor Peran Individu Dalam Organisasi Kerja}

Hipotesis (H0) yang dipergunakan adalah kualitas listrik menurun, peningkatan material sisa dan kerja ulang serta tingkat kecelakaan tinggi merupakan faktor peran individu dalam organisasi yang menyebabkan stres kerja.

Jawaban kuesioner: 1) kualitas listrik menurun 10\%; 2) peningkatan material sisa dan kerja ulang 38\%; 3) tingkat kecelakaan tinggi
0\%. Chi-square distribution table untuk derat kebebasan $\mathrm{df}=2$ dan tingkat signifikansi $\alpha=5 \%$, didapatkan nilai 5,99. Hasil uji Cochran: 1) statistic hitung sebesar 11,556; dan 2) asymptotic significance sebesar 0.003 . Pengambilan keputusan: 1) membandingkan antara nilai statistik hitung dengan nilai statistik table: 11,556 > 5,99, maka Ho Ditolak; 2) membandingkan antara nilai asymptotic significance dengan nilai probabilitas: $\mathbf{0 , 0 0 3}<$ 0,05, maka H0 Ditolak.

Kesimpulan: kualitas listrik menurun (tegangan dan frekuensi), peningkatan sisa produksi dan kerja ulang serta tingkat kecelakaan tinggi merupakan faktor peran individu dalam organisasi yang bukan menyebabkan risiko stres kerja.

\section{Faktor Pengembangan Karier}

Hipotesis (H0) yang dipergunakan adalah sering penggantian karyawan dan organisasi disesuaikan dengan kompetensi pekerja merupakan faktor pengembangan karier yang menyebabkan risiko stres kerja.

Jawaban kuesioner: 1) sering penggantian karyawan 14\%; 2) kesesuaian kompetensi 67\%. Chi-square distribution table untuk derat kebebasan $\mathrm{df}=1$ dan tingkat signifikansi $\alpha=5 \%$, didapatkan nilai 3,84. Hasil Uji Cochran:1) statistic hitung sebesar 8,067; dan 2) asymptotic significance sebesar 0,007. Pengambilan keputusan: 1) membandingkan antara nilai statistik hitung dengan nilai statistik table: 8,067 > 3,84, maka Ho Ditolak; 2) membandingkan antara nilai asymptotic significance dengan nilai probabilitas: $\mathbf{0 , 0 0 7}<$ 0,05, maka H0 Ditolak.

Kesimpulan: pekerjaan sering dilakukan penggantian karyawan dan organisasi berusaha menyesuaikan kompetensi pekerja dengan pekerjaannya merupakan faktor pengembangan karier yang bukan menyebabkan risiko stres kerja.

\section{Faktor Struktur Organisasi dan Suasana Kerja}

Hipotesis (H0) yang dipergunakan adalah sering dilakukan penggantian karyawan, kesulitan mengikuti rapat produksi, penyesuaian kompetensi dengan pekerjaan, tambahan 
pekerja untuk menyelesaikan tugas, pekerja mengeluh kelelahan setelah bekerja, kesulitan memahami instruksi kerja dan pencapaian target kinerja dibutuhkan waktu lembur adalah faktor struktur organisasi dan suasana kerja yang menyebabkan risiko stres kerja.

Jawaban kuesioner: 1) sering penggantian tenaga kerja 14\%; 2) kesulitan mengikuti rapat produksi 38\%; 3) penyesuaian kompetensi dengan pekerjaan 67\%; 4) penyelesaian tugas memerlukan tambahan pekerja 67\%; 5) pekerja mengeluh kelelahan setelah bekerja 29\%; 6) kesulitan memahami instruksi kerja 10\%; 7) pencapaian target kinerja membutuhkan waktu lembur 24\%. Chi-square distribution table untuk derat kebebasan $\mathrm{df}=6$ dan tingkat signifikansi $\alpha=5 \%$, didapatkan nilai 12,59. Hasil Uji Cochran: 1) statistic hitung sebesar 31,438; dan 2) asymptotic significance sebesar 0. Pengambilan keputusan: 1) membandingkan antara nilai statistik hitung dengan nilai statistik table: 31,438 > 12,59, maka Ho Ditolak; 2) membandingkan antara nilai asymptotic significance dengan nilai probabilitas: $\mathbf{0}<\mathbf{0 , 0 5}$, maka Ho Ditolak.

Kesimpulan: sering penggantian pekerja, kesulitan mengikuti rapat produksi, penyesuaian kompetensi, penambahan pekerja, kelelahan setelah bekerja, sulit memahami instruksi kerja dan overtime adalah faktor struktur organisasi dan suasana kerja yang bukan menyebabkan risiko stres kerja.

\section{Faktor Somatis}

Hipotesis (H0) yang dipergunakan adalah pekerja sering berobat ke poliklinik, pekerja mengeluh kelelahan setelah bekerja dan pekerja harus berjalan jauh untuk mendapatkan air minum merupakan faktor somatis yang menyebabkan stres kerja.

Jawaban kuesioner: 1) frekuensi pekerja berobat ke poliklinik 14\%; 2) pekerja mengeluh kelelahan setelah bekerja 29\%; 3) pekerja harus berjalan jauh untuk mendapatkan air minum: 5\%. Chi-square distribution table untuk derat kebebasan $\mathrm{df}=2$ dan tingkat signifikansi $\alpha=5 \%$, didapatkan nilai 5,99. Hasil Uji Cochran: 1) statistik hitung sebesar 4,222; dan 2) asymptotic significance sebesar 0,121. Pengambilan keputusan: 1) membandingkan antara nilai statistik hitung dengan nilai statistik table: 4,222 < 5,99, maka H0 Diterima; 2) membandingkan antara nilai asymptotic significance dengan nilai probabilitas: $\mathbf{0 , 1 2 1}>$ 0,05, maka H0 Diterima.

Kesimpulan: Status kesehatan pekerja, kelelahan setelah bekerja dan kesulitan mendapatkan air minum merupakan faktor somatis penyebab risiko stres kerja.

\section{Faktor Ergonomi}

Hipotesis (H0) yang dipergunakan adalah postur janggal, menjangkau ketinggian, badan memutar, gerakan berulang, energi besar, keleluasaan ruang dan penggunaan peralatan bergetar selama bekerja merupakan faktor ergonomic yang menyebabkan risiko stres kerja.

Jawaban kuesioner: 1) postur tidak alamiah 19\%; 2) menjangkau dan memutar badan 43\%; 3) gerakan berulang 76\%; 4) membutuhkan energi besar 67\%; 5) mengangkat beban berat 19\%; 6) mendorong beban berat $14 \%$; 7) membungkuk sampai dibawah lutut 19\%; 8) stasiun kerja cukup luas 71\%; 9) Posisi pengoperasian peralatan membentuk postur janggal 19\%; 10) penggunaan peralatan bergetar $48 \%$. Chi-square distribution table untuk derat kebebasan $\mathrm{df}=9$ dan tingkat signifikansi $\alpha=5 \%$, didapatkan nilai 16,92. Hasil Uji Cochran: 1) statistic hitung sebesar 52,002; dan 2) asymptotic significance sebesar 0. Pengambilan keputusan: 1) membandingkan antara nilai statistik hitung dengan nilai statistik table: $52>\mathbf{1 6 , 9 2}$, maka Ho Ditolak; 2) membandingkan antara nilai asymptotic significance dengan nilai probabilitas: $0<0,05$, maka H0 Ditolak.

Kesimpulan: postur tidak alamiah, menjangkau dan memutar badan, gerakan berulang, membutuhkan energi besar, mengangkat dan mendorong beban berat, membungkuk sampai dibawah lutut, stasiun kerja cukup luas, posisi pengoperasian peralatan membentuk postur janggal, penggunaan peralatan yang bergetar merupakan faktor ergonomic yang bukan menyebabkan risiko stres kerja. 


\section{KESIMPULAN}

Dari penelitian yang telah dilakukan dapat ditarik kesimpulan: penyebab risiko musculoskeletal disorders adalah: 1) Aktivitas Berulang; 2) Sikap Kerja Tidak Alamiah. Sedangkan Penyebab risiko stres akibat kerja adalah: 1) Faktor fisik lingkungan kerja; 2) Faktor somatis. Tindakan pengendalian yang diperlukan untuk melindungi kesehatan pekerja dari resiko penyebab musculoskeletal disorders dan untuk melindungi gangguan kesehatan pekerja dari resiko penyebab stres kerja akibat pajanan fisik lingkungan kerja dan faktor somatis dapat dilakukan sesuai Engineering Control, Administration Control dan penggunaan APD.

\section{ACKNOWLEDGEMENT}

Kami mengucapkan banyak terima kasih kepada Ir. Zuhdi Rahmanto, MM selaku Manajer PT PLN (Persero) PLTGU Cilegon atas izin yang diberikan dan seluruh staf yang telah berpartisipasi dan membantu sehingga penelitian ini dapat terlaksana dan terselesaikan dengan baik.

\section{DAFTAR PUSTAKA}

[1] Suma'mur P.K., MSc., Dr. (2013). Higiene Perusahaan dan Kesehatan Kerja (Hiperkes). Edisi 2. Penerbit CV Sagung Seto. Jakarta.

[2] Kroemer, K.H.E. and Grandjean, E. (1997). Fitting the Task to the Human: A Textbook of Occupational Ergonomics. $5^{\text {th }}$ ed. Taylor \& Francis Inc. London.

[3] Peter, VI. (2004). Muskuloskeletal Disorders. Taylor and Francis. London.

[4] Anis, J.F. \& McConville, J.T. (1996). Anthropometry. Edited by Bhattacharya, A. and McGlothlin, J.D. (1996). Occupational Ergonomics: Theory and Application. Marcel Dekker Inc. New York

[5] Waters, T.S. and Putz-Anderson, V. (1996). Manual Material Handling. Edited by Bhattacharya, A. and McGlothlin, J.D. (1996). Occupational Ergonomics: Theory and Application. Marcel Dekker Inc. New York.
[6] Manuaba, A. (2000). Ergonomi, Kesehatan dan Keselamatan Kerja. Editor: Sritomo Wignyosoebroto dan Stefanus Eko Wiranto (2000). Proceeding Seminar Nasional Ergonomi 2000. Guna Wijaya. Surabaya.

[7] Astrand, P.O. and Rodahl, K. (1977). Textbook of Work Physiology: Physiological Bases of Exercise. Second Edition. McGraw-Hill. New York.

[8] Pulat, B.M. (1997). Fundamentals of Industrial Ergonomics. Second Edition. Waveland Press, Inc. Illinois.

[9] Wilson, J.R. and Corlett, N. (2005). Evaluation of Human Work. Third Edition. Taylor \& Francis. London.

[10] Dryastiti, P.E.(2013). Hubungan antara Beban Kerja dengan Tingkat Keluhan Musculoskeletal pada Perawat di ruang Ratna dan Ruang Medical Surgical RSUP Sanglah, Denpasar. Skripsi. Universitas Udayana Denpasar

[11] Patton, P. (1998). Emotional Intelegence di tempat kerja. Ed. Julia Tahitoe. Jakarta

[12] M. C. Hochberg et al., "Guidelines for the medical management of osteoarthritis. Part II. Osteoarthritis of the knee. American College of Rheumatology.," Arthritis Rheum., 1995

[13] Wantoro, B. 1999. Stres Kerja. Majalah Hiperkes dan Keselamatan Kerja. Jakarta. Vol. XXXII (3): 3-9.

[14] Cartwright, S., Cooper, C. L., \& Murphy, L. R. (1995). Diagnosing a healthy organization: A proactive approach to stress in the workplace. In L. R. Murphy, J. J. Hurrell, Jr., S. L. Sauter, \& G. P. Keita (Eds.), Job stress interventions (pp. 217-233). Washington, DC, US: American Psychological Association

[15] Cooper, C. L., \& Payne, R. L. (1992). International perspectives on research into work, well-being, and stress management. In J. C. Quick, L. R. Murphy, \& J. J. Hurrell (Eds.). Stress \& well-being at work: Assessments and interventions for occupational mental health (pp. 348-368). Washington, DC, US: American Psychological Association. 